\title{
Response of Maize (Zea mays L.) to Moisture Stress under Different Nitrogen Fertilization Levels
}

Ewis, M. M. ; K. M. Abd El-Latif and M. I. Badawi

Soils, Water \& Environ. Res. Inst., Agric. Res. Center, Giza, Egypt

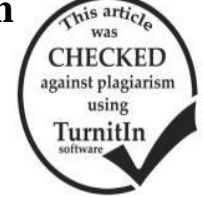

\begin{abstract}
Two field experiments were conducted at Farm of Sids Agricultural Research Station, Egypt, during 2013 and 2014 seasons to study the effect of different irrigation regimes $\left(\mathrm{I}_{1}=100 \%, \mathrm{I}_{2}=85 \%\right.$ and $\mathrm{I}_{3}=70 \%$ from irrigation requirements) and nitrogen levels $\left(90,120\right.$ and $150 \mathrm{~kg} \mathrm{~N} \mathrm{fed}^{-1}$ ) on maize growth, yield and its yield attributes and some crop-water relationships. The most important results could be summarized as follows:Irrigated maize plants with full irrigation produced higher values of plant height, ear diameter, 100- grain weight, weight of grains ear ${ }^{-1}$ and grain yield as well as total amount of irrigation water applied, seasonal consumptive use and the net income. Irrigated maize plants with $80 \%$ from irrigation requirements gave the highest values of water use efficiency and utilization efficiency.Supplied maize plants with $150 \mathrm{~kg} \mathrm{~N}_{\text {fed }}{ }^{-1}$ induced highest values of the abovementioned growth, yield and its attributes and net income as well as improve seasonal consumptive use, water use efficiency and utilization efficiency.Irrigated maize plants with full irrigation requirements and supplied with $150 \mathrm{~kg} \mathrm{~N}^{\mathrm{N}} \mathrm{ed}^{-1}$ produced highest yield and net income of maize plants.
\end{abstract}

Keywords: Maize yield, yield components, irrigation requirements, nitrogen fertilization levels and crop - water relations.

\section{INTRODUCTION}

The rapid inclination of population growth worldwide in general and in the developing countries in particular forces to increase food production and expansion of agricultural lands (Elias et al, 2014). In contrary to the water need for irrigation of agricultural land for enhancing crop production, there is an increasing demand for limited water resource for municipality, industries and for natural resource rehabilitation. Moreover, agriculture is the highest water consuming sector worldwide (Biswas 1997, Abu-Zied, 1999 and Pereira 2006).

Maize (Zea mays L.) is one of the most important crop worldwide after rice and wheat because of its high grain and forage yields and the cultivated area of maize in 2013 was 703,921 hectares with average productivity equals 7.72 ton/ha under surface irrigation (Zohry and Ouda, 2015 and Abdullah et al, 2015). Maize growth and yield are most sensitive to nitrogen application under moisture stress condition. Improper fertilizer and water management are the two major factors adversely affecting maize growth and productivity under dry land condition. The main objective in agriculture production, so far, focused mostly on the increasing of yield and production (Ulusoy, 2001 and Amanullah et al, 2014).

Efficient water management under moisture stress could enhance the crop productivity in the coming decades (Yudelman 1994). Poor water availability and high temperatures result significant stress during critical phases of maize development (Al-Kaisi et al, 2013). Payero et al. (2006) reported that deficit irrigation of maize distributed over the entire crop growing season might not always result in increasing crop water productivity. They added that maize yield due to deficit irrigation at $50 \%$ and $75 \%$ levels as compared to the full irrigation would highlight the issues of irrigation water management in the regions with limiting water supply. Karam et al. (2007) showed that with increasing drought stress grain yield and its components decreased. Water use efficiency is an important crop index used to assess how soil water is used efficiently for total biomass and grain yield production (Daniel et al, 2011).
Elias et al, 2014 reported that moisture stress applied at some growth stages enhance water use efficiency of maize without significantly reducing the yield. Abdullah et al. (2015) stated that maize growth and net income decreased with decreasing in the amount of irrigation. Sani et al. (2008) reported that water use and water use efficiency for maize were the highest with application of full consumptive use requirement at each growth stage. Masoero et al. (2013) found that the total amount of irrigation water was $494 \mathrm{~mm}$ under full irrigation. In Egypt, Yousri (2014) reported that the amount of applied water for maize under full irrigation was 8143.0 $\mathrm{m}^{3} /$ ha. He added that the full irrigation regime improved maize yield, stem diameter, grain weight and 1000-grain weight. In connection, Khalil and Mohamed (2006) found that applying full irrigation significantly increased maize grain yield and yield components. In maize, the reduction in grain yield caused by drought ranges from 10 to $76 \%$ depending on the severity of the drought and the growth stage at which it occurs (Bolaoos et al, 1993). Payero et al. (2006) stated that deficit irrigation at any crop growth stage of the maize crop led to decrease grain yields, and deficit irrigation that spanned across two or more growth stages affect grain production drastically.

The low fertility status of most tropical soils hindered maize production as maize has strong exhausting effect on the soil. It was generally observed that maize fail to produce good grain in plots without adequate nutrients (Adediran and Banjoko, 2003). Therefore, the supply of nitrogen is important for crop maize production as much as water. On the other hand, indiscriminate use of nitrogen leads to increase in production costs and environmental contamination (Gurpreet et al, 2013). Inorganic nitrogen fertilizer exert strong influence on plant growth, development and yield (Stefano et al, 2004). The availability of sufficient nutrients from inorganic fertilizers lead to improved all activities, enhanced cell multiplication and enlargement and luxuriant growth (Fashina et al, 2002). Luxuriant growth resulting from nitrogen fertilizer application leads to larger dry matter production (Obi et al, 2005), owing better utilization of solar radiation and more 
nutrient (Saced et al, 2001). In Egypt, many workers such as Ismail et al. (1999), Ismail et al. (2006), Sadik et al. (2009), Ali et al. (2012) and Abd El-Hafeez et al. ( 2013) stated that increasing nitrogen levels were significantly increased growth yield and its components of maize. Moreover, Matusso (2016). Reported that increases of $\mathrm{N}$ fertilizer level led to increase of yield and yield components. Dawadi and Sah (2012) found that 100 -grain weight, grain weight/ear, and plant height increases with increasing nitrogen levels.

Conditions of water and nitrogen stress lead to reductions in crop production by reducing resource capture and resource use efficiency. It has been reported that maize grown under conditions of limited water supply requires less nitrogen to achieve the maximum grain yield than that required with well water supply (Moser et al, 2006). Meysam and Sarangi (2013) reported that maximum grain yield and biomass were observed for full irrigation and full nitrogen treatments.
The main objective of this study are to investigate the effect of different levels of irrigation water and nitrogen fertilization on maize growth and yield and its components as well as some water-crop relations.

\section{MATERIALS AND METHODS}

\section{Experiment setup:}

The present research trials were conducted during 2013 and 2014 summer seasons at the Experiment Farm of Sids Agricultural Research Station, Beni Swief Governorate (Middle Egypt, Lat. 29 04' N, Long. 31 $06^{\prime} \mathrm{E}$ and $30.40 \mathrm{~m}$ above the mean sea level). Some physiochemical properties and soil-moisture constants of the experimental site, determined according to Page et al. (1982) and Klute (1986) are listed in Tables 1 and 2.

Table 1. Soil particle size distribution and some chemical properties of the experimental site in 2013 and 2014 season.

\begin{tabular}{|c|c|c|c|c|c|c|c|c|c|c|}
\hline \multirow{3}{*}{ Seasons } & \multicolumn{3}{|c|}{$\begin{array}{l}\text { Particle size } \\
\text { distribution* }\end{array}$} & \multirow{3}{*}{$\begin{array}{l}\text { Textural } \\
\text { class }\end{array}$} & \multicolumn{6}{|c|}{ Chemical properties** } \\
\hline & Clay & Silt & Sand & & O.M. & $\mathrm{EC} \mathrm{dSm} \mathrm{m}^{-1}$ & Av & lable & opm) & \\
\hline & & $\%$ & & & $(\%)$ & $(1: 5)$ & $\mathbf{N}$ & $\mathbf{P}$ & K & $(1: 2.5)$ \\
\hline 2013 & 50.20 & 33.45 & 16.35 & & 1.55 & 0.55 & 34.00 & 18.20 & 213.90 & 7.85 \\
\hline 2014 & 50.18 & 32.47 & 17.35 & clay & 1.70 & 0.60 & 32.80 & 19.75 & 224.31 & 7.90 \\
\hline
\end{tabular}

Table 2. Some soil water constants and bulk density of the experimental site.

\begin{tabular}{|c|c|c|c|c|c|}
\hline Seasons & $\begin{array}{c}\text { Soil } \\
\text { Depth } \\
\text { (cm) }\end{array}$ & $\begin{array}{c}\text { Field } \\
\text { capacity } \\
(\%, w / w) *\end{array}$ & $\begin{array}{c}\text { Wilting } \\
\text { point } \\
(\%, \mathrm{w} / \mathrm{w}) *\end{array}$ & $\begin{array}{c}\text { Available water } \\
(\%, w / w)^{*}\end{array}$ & $\begin{array}{c}\begin{array}{c}\text { Bulk } \\
\text { density } \\
\left(\mathrm{gc} \mathrm{m}^{-3}\right)^{*}\end{array} \\
\end{array}$ \\
\hline \multirow{4}{*}{2013} & $00-15$ & 45.08 & 21.58 & 23.50 & 1.13 \\
\hline & $15-30$ & 37.95 & 18.04 & 19.91 & 1.24 \\
\hline & $30-45$ & 35.95 & 17.32 & 18.63 & 1.28 \\
\hline & $45-60$ & 33.14 & 16.04 & 17.10 & 1.32 \\
\hline \multirow[t]{2}{*}{ Mean } & & 38.03 & 18.25 & 19.79 & 1.27 \\
\hline & $00-15$ & 44.56 & 22.17 & 22.39 & 1.17 \\
\hline \multirow{3}{*}{2014} & $15-30$ & 37.09 & 17.66 & 19.43 & 1.29 \\
\hline & $30-45$ & 35.55 & 16.92 & 18.63 & 1.35 \\
\hline & $45-60$ & 33.19 & 15.80 & 17.39 & 1.37 \\
\hline Mean & & 37.60 & 18.14 & 19.46 & 1.30 \\
\hline
\end{tabular}

* According to Klute (1986) **according to Page et al. (1982)

The treatments were laid out in a split-plot experimental design with four replicates. Deficit irrigation treatments were allocated at the main plots, while the assessed nitrogen fertilizer in the form of ammonium sulphate $(20.5 \%)$ levels were occupied the sub-plots as follows:

Main plots (Irrigation levels, I):

$\mathrm{I}_{1}=100 \%$ Irrigation requirements (Full Irrigation), $\mathrm{I}_{2}=85 \%$ from irrigation requirements and $\mathrm{I}_{3}$ $=70 \%$ from irrigation requirements (the irrigation treatments were started after the life irrigation).

Sub plots (Nitrogen fertilization rates, $\mathbf{N}$ ): $=150 \mathrm{~kg} \mathrm{~N} \mathrm{fed}^{-1}$

$$
\mathrm{N}_{1}=90 \mathrm{~kg} \mathrm{~N} \text { fed }^{-1}, \mathrm{~N}_{2}=120 \mathrm{~kg} \mathrm{~N} \text { fed }^{-1} \text { and } \mathrm{N}_{3}
$$

Maize grains of Single- Cross 10 at the rate of $15 \mathrm{~kg} \mathrm{fed}^{-1}$. were sown on 20 and 25 of May and harvested on 23 and 25 of September in 2013 and 2014 seasons, respectively.
Fertilization was carried out according to the recommendation of the Ministry of Agriculture in Egypt as follow: superphosphate and potassium sulphate were applied with equipment of soil for planting at rates 30 $\mathrm{kg}_{2} \mathrm{O}_{5}$ and $48 \mathrm{~kg} \mathrm{~K}_{2} \mathrm{O}$ fed $^{-1}$, respectively. The other usual cultural processes of maize plants were practiced. At harvesting time ten plants were chosen randomly from the two inner rows of each sub-plot and following data were measured: Plant height $(\mathrm{cm})$, ear diameter $(\mathrm{cm})$, grain weight ear $^{-1}(\mathrm{~g}), 100$ - grain weight $(\mathrm{g})$ and grain yield $\left(\mathrm{kg} \mathrm{fed}^{-1}\right)$. The quantity of applied irrigation water was measured using flow-meter attached to the irrigation pump.

Data collected for the studied variables were subjected to statistical analysis using M-Stat computer package to calculate $\mathrm{F}$ ratio according to (Senedecor and Cochran, 1980). The means were compared using Least Significant Difference (LSD) at 5\% level according to Waller and Duncan 1969. 


\section{Water relations:}

Water consumptive use (CU):

To determining water consumptive use, soil samples were taken using a regular auger just before and 48 hours after each irrigation and at harvest time in $15 \mathrm{~cm}$ depth from soil surface down to $60 \mathrm{~cm}$ of soil profile. Water consumptive use was calculated according to Israelsen and Hansen (1962) as follows:

$$
\mathbf{C U}=\frac{\left(\mathbf{Q}_{2}-\mathbf{Q}_{1}\right)}{-100} \times \mathbf{1 0 0} \text { X D Bd }
$$

\section{Where:}

$\mathrm{CU}=$ Water consumptive use, $\mathrm{cm}$

$\mathrm{Q}_{2}=$ Soil layer moisture content, wt $/ \mathrm{wt} \%, 48$ hours after irrigation.

$\mathrm{Q}_{1}=$ Soil layer moisture content, wt/wt \%, Just before irrigation.

$\mathrm{D}=$ Effective root zone, $60 \mathrm{~cm}$.

$\mathrm{Bd}=$ Bulk density of soil layer, $\mathrm{g} \mathrm{cm}^{-3}$

Water consumptive use as $\left(\mathrm{m}^{3} \mathrm{fed}^{-1}\right)$ was obtained by multiplying the value of WCU (m) by $4200 \mathrm{~m}^{2}$.

\section{Water use efficiency (WUE):}

WUE of a crop is a function of multiple factors, including physiological characteristics of maize, genotype, and soil characteristics, meteorological conditions, and agronomic practices. Water use efficiency in $\mathrm{kg} \mathrm{m}^{-3}$ was estimated for each treatment according to the equation described by Vites (1965) as follow:

$$
\text { WUE }\left(\mathrm{kg} \mathrm{m}^{-3}\right)=\text { Grain yield }\left(\mathrm{kg} \mathrm{fed}{ }^{-1}\right) /
$$
Consumptive use $\left(\mathrm{m}^{3}\right.$ fed $\left.^{-1}\right)$

Water utilization efficiency (WUtE):

Water utilization efficiency (WUtE) values were calculated according to Jensen (1983) as follow:

WUtE $\left(\mathrm{kg} \mathrm{m}^{-3}\right)=$ Grain yield $\left(\mathrm{kg} \mathrm{fed}^{-1}\right) /$ Applied irrigation water $\left(\mathrm{m}^{3} \mathrm{fed}^{-1}\right)$ Applied irrigation water was recorded by a flow meter installed in the main unit of irrigation water.

Economical evaluation :

Economic evaluation aims to study the economic evaluation of the experimental treatments.
This study will be done through calculation of the differences between costs of production (L.E. fed ${ }^{-1}$ ) and incomes profits (L.E. fed ${ }^{-1}$ ) to obtain the net return (L.E. $\mathrm{fed}^{-1}$ ) of treatments, will be determine the best treatments that achieved the highest financial return (L.E. fed ${ }^{-1}$ ). All costs of production and incomes profits were mathematically changed to be per feddan. On the other hand, incomes profits were calculated from the actually prices of average maize production per ton fed ${ }^{-1}$ equal 2300 L.E. (Economic Bulletin of Ministry of Agric., Egypt issued in, 2013). The total production costs are calculated as follow:

- Irrespective of irrigation and fertilizer cost, the other cultural practices cost about 2080 L.E. fed ${ }^{-1}$.

- The cost of irrigation treatments were: $413.33,351.33$ and 289.33 L.E. fed ${ }^{-1}$ for $\mathrm{I}_{1}, \mathrm{I}_{2}$ and $\mathrm{I}_{3}$ respectively.

- The costs nitrogen fertilization are calculated as 6.83 L.E. for one kilogram nitrogen.

\section{RESULTS AND DISCUSSION}

\section{Growth and yield components:-}

The measured plant height, ear diameter, 100 grain weight and grain weight ear $^{-1}$ were significantly affected due to the adopted irrigation treatments, (Table 3 ). The highest values of the abovementioned growth and yield attributes were recorded with full irrigation $\left(\mathrm{I}_{1}\right)$, which increased by $8.08,3.86,2.01$ and 5.56 ; and $15.61,6.53,18.89$ and $12.55 \%$ comparable with those irrigated under $\mathrm{I}_{2}$ and $\mathrm{I}_{3}$ treatments in the first season, respectively. Such findings are in parallel with those of Khalil and Mohamed (2006) who found that applying full irrigation practice significantly increased grain yield components for maize. Moreover, Ghooshchi et al. (2008) found that water stress before silking, at silking or grain filling growth stages caused a significant reduction in grains No cob-1 and 1000-grain weight comparing with normal irrigation.

Table 3. Plant height, ear diameter, 100 grain weight, grain weight ear $^{-1}$ and grain yield as affected by

\begin{tabular}{|c|c|c|c|c|c|c|c|c|c|c|c|c|c|c|c|c|c|c|c|c|}
\hline \multirow{3}{*}{ Irrigation } & \multirow{2}{*}{\multicolumn{4}{|c|}{ Plant height (cm) }} & \multirow{2}{*}{\multicolumn{4}{|c|}{ Ear diameter $(\mathbf{c m})$}} & \multirow{2}{*}{\multicolumn{4}{|c|}{$\begin{array}{c}\text { 100-grain weight }(\mathrm{g}) \\
\text { N-fertilizer (2013 season) }\end{array}$}} & \multirow{2}{*}{\multicolumn{4}{|c|}{ 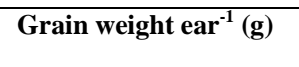 }} & \multirow{2}{*}{\multicolumn{4}{|c|}{ Grain yield $\left(\mathrm{kg} \mathrm{fed}^{-1}\right)$}} \\
\hline & & & & & & & & & & & & & & & & & & & & \\
\hline & $\mathbf{N}_{1}$ & $\mathbf{N}_{2}$ & $\mathbf{N}_{3}$ & Mean & $\mathbf{N}_{1}$ & $\mathbf{N}_{2}$ & $\mathbf{N}_{3}$ & Mean & $\mathrm{N}_{1}$ & $\mathbf{N}_{2}$ & $\mathbf{N}_{3}$ & Mean & $\mathbf{N}_{1}$ & $\mathbf{N}_{2}$ & $\mathbf{N}_{3}$ & Mean & $\mathbf{N}_{1}$ & $\mathbf{N}_{2}$ & $\mathbf{N}_{3}$ & Mean \\
\hline$\overline{\mathrm{I}_{1}}$ & 261.5 & 268.0 & 281.5 & 270.3 & 4.35 & 4.60 & 4.75 & 4.57 & 31.77 & 33.08 & 34.09 & 32.98 & 279.3 & 323.9 & 354.3 & 319.2 & 2931 & 3334 & 3799 & 3355 \\
\hline $\mathrm{I}_{2}$ & 235.5 & 247.8 & 267.0 & 250.1 & 4.10 & 4.45 & 4.65 & 4.40 & 30.96 & 32.79 & 33.23 & 32.33 & 271.8 & 304.8 & 330.5 & 302.4 & 2654 & 3074 & 3457 & 3062 \\
\hline $\mathrm{I}_{3}$ & 214.8 & 228.3 & 258.5 & 233.8 & 4.05 & 4.30 & 4.50 & 4.29 & 26.93 & 27.46 & 28.83 & 27.74 & 254.2 & 291.3 & 305.2 & 283.6 & 2148 & 2507 & 3058 & 2571 \\
\hline Mean & 237.3 & 248.0 & 269.0 & 251.4 & 4.17 & 4.45 & 4.63 & 4.42 & $\begin{array}{l}29.87 \\
\text { L.S.D }\end{array}$ & $\begin{array}{l}31.11 \\
\text { at } 0.05\end{array}$ & 32.05 & 31.02 & 268.4 & 306.7 & 330.0 & 301.7 & 2578 & 2972 & 3438 & 2996 \\
\hline Irrigation & \multicolumn{4}{|c|}{7.42} & \multicolumn{4}{|c|}{0.16} & \multicolumn{4}{|c|}{0.91} & \multicolumn{4}{|c|}{38.39} & \multicolumn{4}{|c|}{287.2} \\
\hline Nitrogen & \multicolumn{4}{|c|}{7.48} & \multicolumn{4}{|c|}{0.10} & \multicolumn{4}{|c|}{1.52} & \multicolumn{4}{|c|}{18.71} & \multicolumn{4}{|c|}{201.4} \\
\hline Interaction & \multicolumn{4}{|c|}{12.97} & \multicolumn{4}{|c|}{0.18} & \multicolumn{4}{|c|}{2.63} & \multicolumn{4}{|c|}{32.42} & \multicolumn{4}{|c|}{349.1} \\
\hline \multicolumn{21}{|c|}{ (2014 season) } \\
\hline $\mathrm{I}_{1}$ & 252.0 & 277.8 & 291.8 & 273.8 & 4.40 & 4.65 & 4.70 & 4.58 & 31.36 & 34.6 & 35.16 & 33.71 & 287.6 & 336.9 & 372.0 & 332.2 & 3068 & 3488 & 3981 & 3512 \\
\hline $\mathrm{I}_{2}$ & 224.3 & 253.8 & 281.0 & 253.0 & 4.20 & 4.55 & 4.60 & 4.45 & 31.10 & 33.78 & 34.84 & 33.24 & 277.2 & 313.9 & 339.2 & 310.1 & 2813 & 3177 & 3662 & 3217 \\
\hline $\mathrm{I}_{3}$ & 222.8 & 243.3 & 250.8 & 238.9 & 4.15 & 4.20 & 4.40 & 4.25 & 27.70 & 29.36 & 30.10 & 29.06 & 256.7 & 297.1 & 314.4 & 289.4 & 2296 & 2681 & 3105 & 2694 \\
\hline Mean & 233.0 & 258.3 & 274.5 & 255.2 & 4.25 & 4.47 & 4.57 & 4.43 & $\begin{array}{l}30.05 \\
\text { L.S.D }\end{array}$ & $\begin{array}{l}32.58 \\
\text { at } 0.05\end{array}$ & 33.45 & 32.03 & 273.8 & 316.0 & 341.9 & 310.6 & 2726 & 3115 & 3583 & 3141 \\
\hline Irrigation & \multicolumn{4}{|c|}{20.20} & \multicolumn{4}{|c|}{0.22} & \multicolumn{4}{|c|}{2.66} & \multicolumn{4}{|c|}{41.02} & \multicolumn{4}{|c|}{214.3} \\
\hline Nitrogen & \multicolumn{4}{|c|}{14.33} & \multirow{2}{*}{\multicolumn{4}{|c|}{0.17}} & \multirow{2}{*}{\multicolumn{4}{|c|}{0.87}} & & & .87 & & & & 15.1 & \\
\hline Interaction & & & 4.85 & & & & & & & & & & & & .43 & & & & 72.6 & \\
\hline
\end{tabular}
irrigation, $\mathrm{N}$-fertilizer rates and their interaction in 2013 and 2014 seasons.

$\left(I_{1}, I_{2}\right.$ and $\left.I_{3}\right)$ irrigation treatments : 100, 85 and $70 \%$ from irrigation requirements ; $\left(N_{1}, N_{2}\right.$ and $\left.N_{3}\right)$ nitrogen fertilizer: 90,120 and 150 $\mathrm{kg} \mathrm{N}$ fed $^{-1}$, respectively 
Concerning growth and yield attributes (plant height, ear diameter, 100 -grain weight and grain weight ear $^{-1}$ ) as affected by nitrogen levels, results in Table (3) reveal that the highest values of the investigated growth and yield attributes were recorded with $\mathrm{N}_{3}$ in $1^{\text {st }}$ and $2^{\text {nd }}$ seasons.

The relative increasing caused by $\mathrm{N}_{3}$ treatment compared to $\mathrm{N}_{1}$ and $\mathrm{N}_{2}$ for the abovementioned parameters reached to $13.4,11.0,7.3$, and 23.0; and 8.5, 4.0, 3.0 and $7.6 \%$ in the first season, respectively. The corresponding increasing in the second season were $17.8,7.5,11.3$, and 24.9 ; and $6.3,2.2,2.7$ and $8.2 \%$ in the same respect.

These increment due to increasing nitrogen level is mainly explained to nitrogen is the most important nutrient for plant growth which caused cell developed, then tended be large and function of protoplasm, which consequently increased both growth and yield attributes of plants. These results agree with those obtained by Ismail et al. (2006) and Dawadi and Sah (2012).

The highest values of the studied characters were attained due to interaction of irrigation $(100 \%)$ and nitrogen level $\left(\mathrm{N}_{3}\right)$, and such finding was true in $1^{\text {st }}$ and $2^{\text {nd }}$ seasons. These results are in agreement with Meysam and Sarangi (2013)

Grain yield $\left(\mathrm{kg} \mathrm{fed}^{-1}\right)$ :

The results in Table (3) showed that maize grain yield was significantly affected by irrigation and nitrogen treatments in 2013 and 2014. The data indicated that increasing water amounts resulted in a relatively higher yield, since water deficit was main yield-limiting factor in both years. The maximum yield was obtained at full irrigation $\left(\mathrm{I}_{1}\right)$ and the minimum yield at $70 \%$ from irrigation requirements $\left(\mathrm{I}_{3}\right)$ in 2013 and 2014 seasons. The grain yield under irrigation treatments (full Irrigation $I_{1}, 85 \% I_{2}$ and $70 \%$ from irrigation requirements $\mathrm{I}_{3}$ ) were $3355,3026,2571$ and 3512, 3217, $2694 \mathrm{~kg} \mathrm{fed}^{-1}$ in 2013 and 2014, respectively. The highest grain yield values were recorded with $100 \%$, which exceeded than the other irrigation treatments. The percent increases in grain yield under $I_{1}$ was $9.6,30.5 \%$ and $9.2,30.4 \%$ in $1^{\text {st }}$ and $2^{\text {nd }}$ seasons when compared with $\mathrm{I}_{2}$ and $\mathrm{I}_{3}$ treatments, respectively. The increment in grain yield under sufficiently irrigation can be attributed to the adequate turgidity which must have prevailed inside the plant thereby helping in significantly better shoot development, number of leaves per plant and then higher grain yield. Such findings are in parallel with those reported by El-Tantawy et al. (2007), Jat et al. (2008), Payero et al. (2006), Khalil and Mohamed (2006) and Gurpreet et al. (2013) who found that applying full irrigation practice significantly increased grain yield of maize. Moreover, Traore et al. (2000) stated that water stress can affect growth, development and physiological processes of corn plants, which can reduce biomass and ultimately grain yield.

The highest main values of grain yield 3438 and $3583 \mathrm{~kg} \mathrm{fed}^{-1}$ in both seasons, respectively were obtained under $\mathrm{N}_{3}\left(150 \mathrm{~kg} \mathrm{~N}^{-1} \mathrm{~d}^{-1}\right)$. Comparing with those obtained under $\mathrm{N}_{1}\left(90 \mathrm{~kg} \mathrm{~N}^{-1} \mathrm{~d}^{-1}\right)$ and $\mathrm{N}_{2}(120 \mathrm{~kg}$ $\left.\mathrm{N} \mathrm{fed}{ }^{-1}\right)$. The primitive effect of the high nitrogen fertilization on maize grain yield could be explained by the fact that maize plant responded to great extent to $\mathrm{N}$ fertilization because its nature as a heavy $\mathrm{N}$ feeder crop, as well as the deficit in soil - N (Genaidy et al, 1992). These results are in harmony with those obtained by Abd El-Hafeez et al. (2013) and Matusso (2016).

Results in Table (3) show that maize grain yields significantly affected by the interaction between nitrogen rates and irrigation treatments. Applying 150 $\mathrm{kg} \mathrm{N}$ fed $^{-1}$ and full irrigation gave the highest grain yield, i.e., 3799 and $3981 \mathrm{~kg} \mathrm{fed}^{-1}$ for both growing seasons, respectively.

\section{Irrigation water applied (IWA, $\mathbf{m}^{3} \mathbf{~ f e d ~}^{-1}$ ):}

Data in Table (4) show the amount of irrigation water applied. Planting and second irrigation watering through complete emergence was accompanied with amount of (480 and $\left.490 \mathrm{~m}^{3} \mathrm{fed}^{-1}\right)$ and $\left(365\right.$ and $368 \mathrm{~m}^{3}$ $\left.\mathrm{fed}^{-1}\right)$ in the first and second seasons, respectively for all treatments. The values of water applied were increased under $100 \%$ of full irrigation treatment $\left(I_{1}\right)$ in comparison with the other two treatments of 85 and $70 \%$ from irrigation requirements $\left(\mathrm{I}_{2}\right.$ and $\left.\mathrm{I}_{3}\right)$.

Table 4. Number of irrigation and applied water $\left(\mathrm{m}^{3} \mathrm{fed}^{-1}\right)$ for each irrigation under different irrigation treatments during the 2013 and 2014 seasons.

\begin{tabular}{|c|c|c|c|c|c|c|}
\hline Treatments & & $\mathrm{S}$ & & & & \\
\hline Irrigation event & First & $\begin{array}{l}\text { season } \\
\text { Second }\end{array}$ & First & Second & First & Second \\
\hline Planting irrigation & 480 & 490 & 480 & 490 & 480 & 490 \\
\hline Second & 365 & 368 & 365 & 368 & 365 & 368 \\
\hline Third & 390 & 395 & 332 & 336 & 273 & 277 \\
\hline Fourth & 405 & 410 & 344 & 349 & 284 & 287 \\
\hline Fifth & 415 & 425 & 353 & 361 & 291 & 298 \\
\hline Sixth & 400 & 415 & 340 & 353 & 280 & 291 \\
\hline Seventh & 395 & 405 & 336 & 344 & 277 & 284 \\
\hline Eighth & 370 & 375 & 315 & 319 & 259 & 263 \\
\hline Ninth & 305 & 307 & 359 & 261 & 214 & 215 \\
\hline Total $\left(\mathrm{m}^{3} \mathrm{fed}^{-1}\right)$ & 3525 & 3590 & 3124 & 3181 & 2723 & 2773 \\
\hline
\end{tabular}

$\left(I_{1}, I_{2}\right.$ and $\left.I_{3}\right)$ irrigation treatments : 100, 85 and $70 \%$ from irrigation requirements

The highest values were 3525 and $3590 \mathrm{~m}^{3} \mathrm{fed}^{-1}$ due to $\left(\mathrm{I}_{1}\right)$ treatment. While, the lowest values were recorded under $\left(I_{3}\right)$ treatment as 2723 and $2773 \mathrm{~m}^{3} \mathrm{fed}^{-1}$ due to in the two growing seasons, respectively. The data revealed that $70 \%$ from irrigation requirements $\left(I_{3}\right)$ could saved about 22.75 and $22.76 \%$ of applied water, compared with full irrigation $\left(\mathrm{I}_{1}\right)$ in the $1^{\text {st }}$ and the $2^{\text {nd }}$ seasons, respectively. In addition, under $85 \%$ from 
irrigation requirements $\left(\mathrm{I}_{2}\right)$ the same trend was noticed with reduction percentages values reached about 11.38 and $11.39 \%$, as compared with $\left(\mathrm{I}_{1}\right)$. This is logic and expected result and it is attributable to more irrigation events applied under full irrigation, similar results were obtained by Ouda et al. (2009), Masoero et al. (2013), Yousri (2014) and Khalil and Mohamed (2006) they stated that applying full irrigation practice significantly increased grain yield.

Water consumptive use $\left(\mathrm{Cu}, \mathrm{m}^{3} \mathrm{fed}^{-1}\right)$ :

Average $\mathrm{CU}$ values as affected by irrigation treatments on maize crop in the two growing seasons are presented in Table (5). Data presented indicated that the water consumption was of maize crop as the percentage of water added increased i.e. 100, 85 and $70 \%$, respectively. Data in Table 5 indicated that full irrigation gave higher amount of the average $\mathrm{CU}$ values of 2820 and $2872 \mathrm{~m}^{3} \mathrm{fed}^{-1}$, in 2013 and 2014, respectively. On the other hand, irrigation with 85 and $70 \%$ from irrigation requirements reduced average $\mathrm{CU}$ values to 2217, 2355 and 1970, $2043 \mathrm{~m}^{3} \mathrm{fed}^{-1}$ in 2013 and 2014 respectively. The high water consumptive use for the full irrigation treatment is due to the abundance of soil moisture in the soil and the plants tend to grow without stress in the last stage of growth and hence use more water. These results may be attributed to the amount of irrigation increased and the soil moisture was more available for extraction by plant roots. These results agree with those obtained by Rayan et al. (1999) and Moussa and Abdel-Maksoud (2004) In connection, Oktem et al. (2003), Ayotamuno et al. (2007) and Abd El-Latif et al. (2016) reported that the increment in water consumption by plants depended on availability of soil moisture in the root zone and plant growth stage.

Table 5. Seasonal water applied (IWA, $\mathrm{m}^{3} \mathrm{fed}^{-1}$ ), seasonal consumptive use $\left(\mathrm{CU}, \mathrm{m}^{3} \mathrm{fed}^{-1}\right)$, water use efficiency (WUE, $\mathrm{kg} \mathrm{m}^{-3}$ consumed) and water utilization efficiency (WUtE, $\mathrm{kg} \mathrm{m}^{-3}$ applied) as affected by irrigation treatments in 2013 and 2014 seasons.

\begin{tabular}{|c|c|c|c|c|c|c|c|c|c|c|c|}
\hline $\begin{array}{l}\text { Irrigation } \\
\text { treatments }\end{array}$ & $\begin{array}{c}\text { Nitrogen } \\
\text { Level }\end{array}$ & IWA & $\mathrm{CU}$ & $\begin{array}{c}2013 \\
\text { Grain }\end{array}$ & WUE & WUtE & IWA & $\mathrm{CU}$ & $\begin{array}{r}2014 \\
\text { Grain }\end{array}$ & WUE & WUtE \\
\hline \multirow{3}{*}{$\mathrm{I}_{1}$} & $\mathrm{~N}_{1}$ & & 2620 & 2931 & 1.12 & 0.83 & \multirow{4}{*}{3590} & 2675 & 3068 & 1.15 & 0.85 \\
\hline & $\mathrm{N}_{2}$ & & 2790 & 3334 & 1.19 & 0.95 & & 2810 & 3488 & 1.24 & 0.97 \\
\hline & $\mathrm{N}_{3}$ & 3525 & 3050 & 3799 & 1.25 & 1.08 & & 3130 & 3981 & 1.27 & 1.11 \\
\hline Mean & & & 2820 & 3355 & 1.19 & 0.95 & & 2872 & 3512 & 1.22 & 0.98 \\
\hline \multirow{3}{*}{$\mathrm{I}_{2}$} & $\mathrm{~N}_{1}$ & & 2140 & 2654 & 1.24 & 0.85 & \multirow{4}{*}{3181} & 2210 & 2813 & 1.27 & 0.88 \\
\hline & $\mathrm{N}_{2}$ & & 2175 & 3074 & 1.41 & 0.98 & & 2325 & 3177 & 1.37 & 1.00 \\
\hline & $\mathrm{N}_{3}$ & 3124 & 2335 & 3457 & 1.48 & 1.11 & & 2530 & 3662 & 1.45 & 1.15 \\
\hline Mean & & & 2217 & 3062 & 1.38 & 0.98 & & 2355 & 3217 & 1.36 & 1.01 \\
\hline \multirow{3}{*}{$\mathrm{I}_{3}$} & $\mathrm{~N}_{1}$ & & 1860 & 2148 & 1.15 & 0.79 & \multirow{4}{*}{2773} & 1925 & 2296 & 1.19 & 0.83 \\
\hline & $\mathrm{N}_{2}$ & 3723 & 1925 & 2507 & 1.30 & 0.92 & & 2030 & 2681 & 1.32 & 0.97 \\
\hline & $\mathrm{N}_{3}$ & $2 / 23$ & 2125 & 3058 & 1.44 & 1.12 & & 2175 & 3105 & 1.43 & 1.12 \\
\hline Mean & & & 1970 & 2571 & 1.30 & 0.94 & & 2043 & 2694 & 1.32 & 0.97 \\
\hline Mean of & $\mathrm{N}_{1}$ & & 2207 & 2578 & 1.17 & 0.82 & & 2270 & 2726 & 1.20 & 0.86 \\
\hline & $\mathrm{N}_{2}$ & 3124 & 2297 & 2972 & 1.30 & 0.95 & 3181 & 2388 & 3115 & 1.31 & 0.98 \\
\hline fertilizer & $\mathrm{N}_{3}$ & & 2503 & 3438 & 1.39 & 1.10 & & 2612 & 3583 & 1.38 & 1.13 \\
\hline
\end{tabular}

$\left(I_{1}, I_{2}\right.$ and $\left.I_{3}\right)$ irrigation treatments : 100, 85 and $70 \%$ from irrigation requirements $;\left(N_{1}, N_{2}\right.$ and $\left.N_{3}\right)$ nitrogen fertilizer: 90,120 and 150 $\mathrm{kg} \mathrm{N} \mathrm{fed}^{-1}$, respectively

As for nitrogen treatments, the results clearly show that the water consumptive use values were positively responded to nitrogen levels. Fertilized maize plants with $150 \mathrm{~kg} \mathrm{~N}^{-1} \mathrm{fe}^{-1}$ gave $\mathrm{CU}$ values higher than those supplied with 90 or $120 \mathrm{~kg} \mathrm{~N} \mathrm{fed}^{-1}$ by about 13.4 and $9.0 \%$ in the first season, respectively. Similar trends were obtained in the second season. These results is mostly due to the plants fertilized with $150 \mathrm{~kg} \mathrm{~N} \mathrm{fed}^{-1}$ exerted higher root and shoot growth, consequently consumed more water.

As for the interaction between water and nitrogen treatments, the data, reveal that the plants irrigated with full irrigation requirements and received $150 \mathrm{~kg} \mathrm{~N}$ fed $^{-1}$ recorded the highest $\mathrm{CU}$ values in both seasons. On the other hand the plants watered with $80 \%$ from it requirements and fertilized with $90 \mathrm{~kg} \mathrm{~N}^{-1} \mathrm{fed}^{-1}$ showed the lowest CU values.

Water Use Efficiency (WUE, $\mathrm{kg} \mathrm{m}^{-3}$ ):

The water use efficiency or the productivity of maize grains $\mathrm{kg} \mathrm{m}^{-3}$ obtained from each cubic meter water consumed in both seasons is recorded in Table (5). WUE was different based on the treatments and years. WUE values ranged between 1.12 and $1.48 \mathrm{~kg} \mathrm{~m}^{-}$ ${ }^{3}$ for the both years. The maximum values of WUE were obtained from the $85 \%$ treatment $\left(1.38\right.$ and $1.36 \mathrm{~kg} \mathrm{~m}^{3}$, respectively). Oktem et al. (2003) reported that WUE range of $1.04-1.36 \mathrm{~kg} \mathrm{~m}^{-3}$. However, the range of WUE obtained in this study was higher than those reported by Igbadun et al. (2008) and Pandey et al. (2000). Generally, WUE are influenced by crop yield potential, irrigation treatments and climatic characteristics of the region. The results related to the efficiencies shows that when irrigation water is limited, $25 \%$ deficit irrigation can be applied for increase the water use efficiencies. The present results are in line with those reported by Ghadiri and Majidian (2003), Elias et al. (2014), Abdel Mawly and Zanouny (2005), Yang et al. (2005) and El-Atawy (2007) who mentioned that the efficiency of water use had decreased as the soil moisture was maintained high by the frequent irrigation.

Regarding nitrogen fertilization, the data show that water use efficiency was increased as nitrogen levels increased. The values of WUE under $150 \mathrm{~kg} \mathrm{~N}$ fed $^{-1}$ surpassed that under 90 and $120 \mathrm{~kg} \mathrm{~N}^{-1}$ by about 18.8 and $6.9 \%$ in the first season, respectively. The corresponding increasing in the second season were 15.0 and $5.3 \%$ in the same respect.

Data in Table (5) indicate that maize plants watered with $70 \%$ from irrigation requirements and fertilized with high nitrogen level, i.e. $150 \mathrm{~kg} \mathrm{~N}^{-1}$ 
had a high values of water use efficiency in both seasons, while the lowest one was produced for plants irrigated with full irrigation requirements and fertilized with $90 \mathrm{~kg} \mathrm{~N}$ fed $^{-1}$. Mansouri et al. (2010) reported that irrigation water can be conserved and yields maintained in maize plant (as sensitive crop to drought stress) under water limited conditions through improved fertilizer managements.

Water utilization efficiency (WUtE, $\mathrm{kg} \mathrm{m}^{-3}$ ):

Efficiency water utilization is an important limiting factor to crop production. Water utilization efficiency (WUtE) values for maize yield as affected by the tested variables during 2013 and 2014 growing season are presented in Table (5). Results showed that average water utilization efficiency (WUtE) values were affected by irrigation treatments and nitrogen level treatments. The obtained results in Table (5) indicate that the average water utilization efficiency (WUtE) as affected by irrigation treatments in the two seasons, were $0.95,0.98$ and $0.94 \mathrm{~kg} \mathrm{~m}^{-3}$ under 100,85 and $70 \%$ from irrigation requirements, respectively in the first season. The corresponding value for the second season

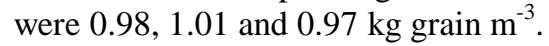

The results obtained show that WUtE was positively responded to increasing nitrogen level up to $150 \mathrm{~kg} \mathrm{~N}$ fed-1 which mainly due to the effect of nitrogen on improving the growth of roots and shoots of maize in turn improved water absorption from soil.

The data for the interaction show that the maximum value of WUtE were 1.11 and $1.15 \mathrm{~kg}$ grain $\mathrm{m}^{-3}$ water applied in 2013 and 2014 seasons, respectively. It was obtained from $\mathrm{I}_{2}$ irrigation treatment and $\mathrm{N}_{3}$ nitrogen fertilizer treatment. While, the lowest value of WUtE was 0.79 and $0.83 \mathrm{~kg} \mathrm{~m}^{-3}$ water applied, was obtained by $\mathrm{I}_{3}$ irrigation treatment and $\mathrm{N}_{1}$ nitrogen fertilizer in 2013 and 2014 seasons, respectively.

\section{Net return :}

Total cost, gross return and net return of maize as affected by different irrigation treatments are presented in Table (6).

Table 6. Economic analysis as affected by different irrigation and nitrogen treatments (average yield of 2 years)

\begin{tabular}{|c|c|c|c|c|c|c|}
\hline \multicolumn{2}{|c|}{ Treatments } & $\begin{array}{c}\text { IWA } \\
\text { med }^{3}\end{array}$ & $\begin{array}{c}\text { Yield } \\
\text { kg }_{\text {fed }^{-1}}\end{array}$ & $\begin{array}{c}\text { Total } \\
\text { production } \\
\text { cost }(\mathbf{L} . \mathbf{E} . \\
\left.\text { fed }^{-1}\right)\end{array}$ & Income & $\begin{array}{c}\text { Net } \\
\text { return }\end{array}$ \\
\hline \multirow{3}{*}{$\mathrm{I}_{1}$} & $\mathrm{~N}_{1}$ & \multirow{4}{*}{3558} & 3000 & 3108 & 6900 & 3792 \\
\hline & $\mathrm{N}_{2}$ & & 3411 & 3313 & 7845 & 4532 \\
\hline & $\mathrm{N}_{3}$ & & 3890 & 3518 & 8947 & 5429 \\
\hline \multirow[t]{2}{*}{ Mean } & & & 3434 & 3313 & 7897 & 4584 \\
\hline & $\mathrm{N}_{1}$ & \multirow{4}{*}{3153} & 2734 & 3046 & 6288 & 3242 \\
\hline \multirow[t]{2}{*}{$\mathrm{I}_{2}$} & $\mathrm{~N}_{2}$ & & 3126 & 3251 & 7190 & 3939 \\
\hline & $\mathrm{N}_{3}$ & & 3560 & 3456 & 8188 & 4732 \\
\hline \multirow[t]{2}{*}{ Mean } & & & 3140 & 3251 & 7222 & 3971 \\
\hline & $\mathrm{N}_{1}$ & \multirow{4}{*}{2748} & 2222 & 2984 & 5111 & 2127 \\
\hline \multirow[t]{2}{*}{$\mathrm{I}_{3}$} & $\mathrm{~N}_{2}$ & & 2594 & 3189 & 5966 & 2777 \\
\hline & $\mathrm{N}_{3}$ & & 3082 & 3394 & 7089 & 3695 \\
\hline Mean & & & 2633 & 3189 & 6055 & 2866 \\
\hline \multirow{3}{*}{$\begin{array}{l}\text { Mean of } \mathrm{N} \\
\text { fertilizer }\end{array}$} & $\mathrm{N}_{1}$ & \multirow{3}{*}{3153} & 2652 & 3046 & 6100 & 3054 \\
\hline & $\mathrm{N}_{2}$ & & 3044 & 3251 & 7000 & 3749 \\
\hline & $\mathrm{N}_{3}$ & & 3511 & 3456 & 8075 & 4619 \\
\hline
\end{tabular}

$\left(I_{1}, I_{2}\right.$ and $\left.I_{3}\right)$ irrigation treatments : 100,85 and $70 \%$ from irrigation requirements ; $\left(\mathrm{N}_{1}, \mathrm{~N}_{2}\right.$ and $\left.\mathrm{N}_{3}\right)$ nitrogen fertilizer: 90 , 120 and $150 \mathrm{~kg} \mathrm{~N}$ fed $^{-1}$, respectively.
The total cost of production increased with increasing both nitrogen and irrigation levels. The results revealed that the full irrigation and increasing nitrogen fertilizer $\left(\mathrm{I}_{1} \mathrm{~N}_{3}\right)$ is the best choice for higher yield $\left(3890 \mathrm{~kg} \mathrm{fed}^{-1}\right)$ and net income (5429 L.E. fed ${ }^{-1}$ ) under the study. The present results are in line with reported by Pandey et al. (2000), who mentioned that the use of full irrigation water management and nutrient application is essential to maximize crop production and returns for the farmers.

\section{CONCLUTION}

It could be recommended to irrigated maize plants with $100 \%$ from irrigation requirements and fertilized with $150 \mathrm{~kg} \mathrm{~N}^{-1} \mathrm{f}^{-1}$ for high production and net income.

\section{REFERENCES}

Abdullah, K.; K. Hayrettin; Ö. Mehmet and B. Gamze (2015). The Effect of different irrigation water levels on grain yield, yield components and some quality parameters of silage maize (Zea mays indentata Sturt.) in Marmara Region of Turkey. Not Bot Horti Agrobo, (1):138-145.

Abd El-Hafeez, A.M.; H.A. Awadalla and S.A. Ismail (2013). Influence of different sources and levels of nitrogen and rock phosphate addition on maize productivity and soil fertility. J. Soil Sci. and Agric Eng., Mansoura Univ., 4(11):13131328.

Abd El-Latif, K.M., M.A. Mahmoud, M.M. Ewis and M.F.I. El-Akram (2016). Effect of skipping the last irrigation on the productivity and some water relations of four maize hybrids under Middle Egypt conditions. $1^{\text {st }}$ International Conference on Applied Microbiology-March 13, Giza, Egypt,:163-178.

Abdel Mawly, S.E. and I. Zanouny (2005). Irrigation and fertilization management for maximizing crop-water efficiencies of maize. Minia. J. Agric. Res. \& Develop., Egypt, 25(1): 125-146.

Abu-Zied, M. (1999). Egypt's Water Policy for the 21 Century, 7 Nile Conference, March 15-19, Cairo, Egypt.

Adediran, J.A. and V.A. Banjoko (2003). Comparative effectiveness of some compost fertilizer formulations for maize in Nigeria. Nig. J. Soil Sci., 13:42-48.

Ali, M.E.; S.A. Ismail; A.H. El-Hameid; O.H.M. ElHussieny and F.H. El-Sheref-Ghada (2012). Effect of natural fertilizers under different levels of nitrogen and farmyard manure on productivity of maize. Fayoum J. Agric. Res. \& Dev., 26(1):49-63.

Al-Kaisi, M.M.; R.W. Elmore; J.G. Guzman; H.M. Hanna; C.E. Hart; M.J. Helmers; E.W. Hodgson; A.W. Lenssen; A.P. Mallarino; A.E. Robertson and J.E. Sawyer (2013). Drought impact on crop production and the soil environment: 2012 experiences from Iowa. Journal of Soil \& Water Conservation,68:19-24.

Amanullah; Khair M. K.; K. Azam; K. Imran; S. Zahir and Z. Hussain (2014). Growth and yield response of maize (Zea mays L.) to foliar NPKfertilizers under moisture stress condition. Soil Environ. 33(2): 116-123. 
Ayotamuno, J.M.; K. Zuofa; O. A. Sunday and R. B. Kogbara (2007). Response of maize and cucumber intercrop to soil moisture control through irrigation and mulching during the dry season in Nigeria. African Journal of Biotechnology, 6 (5): 509-515.

Biswas, Asit K. (1997). Water Development and Environmental Resources. Environmental Planning, Management, and Development. A. K. Biswas, eds. TATA McGRAW. HILL.

Bulletin Ministry Agric., Egypt Economic Issu. (2013). Estimated average cost of production for field crops.

Bolaoos, J.; G.O. Edmeades and L. Martinetz (1993). Eight cycles of selection for drought tolerance in lowland tropical maize. III. Response in drought adaptive physiological and morphological traits. Field Crops Res.31:26986.

Daniel, K.A.; O.F. Justice; O.A. Emmanuel and M.A. Harry (2011). Water use efficiencies of maize cultivars grown under rain-fed conditions. Agricultural Sciences, 2 (2): 125-130.

Dawadi, D.R. and S.K. Sah (2012). Growth and yield of hybrid maize (Zea mays L.) in relation to planting density and nitrogen levels during winter season in Nepal. Tropical Agricultural Research, 23 (3): 218 - 227.

El-Atawy, E.E.I. (2007). Irrigation and fertilization management under the conditions of Kafr ElSheikh Governorate soil. Ph.D. Thesis, Soil Dept. Fac. of Agric., Mansoura Univ., Egypt.

El-Tantawy, M.M.; S. A. Ouda and F.A. Khalil (2007). Irrigation scheduling for maize crop grown under middle Egypt conditions. Res. J. Agric. and Biol. Sci., 3 : 456-62.

Elias, M.; M. Mulugeta and H. Tilahun (2014). Response of maize (Zea mays L.) for moisture stress condition at different growth stages. International Journal of Recent Research in Life Sciences, 1 (1): 12-21.

Fashina, A. S.; K. A. Olatunji and K. O. Alasiri (2002). Effects of different plant population and poultry manure on yield of Ugu (Telfairia occidentalis) in Lagos State, Nigeria in Proceedings of the annual Conference of Horticultural Society of Nigeria (HORTON), pp. 123-127.

Genaidy, S.; M. Sobh; M. Hegazy and A.R. Ahmed (1992). Nitrogen and phosphorus fertilizers requirement and time of application to maize (Zea mays L.). Egypt J. Agric. Res., 70(2): 339351 .

Ghadiri, H. and M. Majidian (2003). Effect of different nitrogen fertilizer levels and moisture stress during milky and dough stages on grain yield, yield components and water use efficiency of corn (Zea mays L.). Journal of Science and Technology of Agriculture and Natural resources, 7(2): 103-113.

Ghooshchi, F.; M. Seilsepour and P. Jafari (2008). Effects of water stress on yield and some agronomic traits of maize [SC 301]. AmericanEurasian J. Agric. \& Environ. Sci., 4 (3): 302305.

Gurpreet, S.A.; K.V. Krishan and S.S. Maha (2013). Effect of different irrigation regimes and nitrogen levels on growth parameters and yield of late kharif sown maize (Zea mays L.). Crop Res. 45 (1, 2 \& 3) : 96-105.
Igbadun, H.E.; B.A. Salim; A.K.P.R. Tarimo and H.F. Mahoo (2008). Effects of deficit irrigation scheduling on yields and soil water balance of irrigated maize. Irrig. Sci., 27:11-23.

Ismail, S.A.; M.A.Morsy; S.S. Awad and F.S. Salem (1999). Effect of some maize varieties, nitrogen fertilization levels and zinc application on grain and stalk, yields, total $\mathrm{N}$ and $\mathrm{Zn}$ uptake and protein content. Fayoum J. Agric., Res. \& Dev., 13(1): 57-68.

Ismail, S.A.; M.A. Morsy; A.A. Omran and M.M. Foaad (2006). The productivity of some hybrids (Zea mays L.) grown in an alluvial soil under different nitrogen sources and levels. The Second Conference on Farm Integrated Pest Management. Fac. of Agric. Fayum Univ., 1618 January, Egypt.

Israelsen, O.W. and V.E. Hansen (1962). Irrigation Principles and Practices, $3^{\text {rd }}$ edit. John Wiley and Sons, Inc., New York, USA.

Jat, M. L.; S.S. Pal; R. Singh; D. Singh and M.S. Gill (2008). Effect of moisture regimes and nitrogen management options on crop and water productivity and nitrogen-use efficiency in maize (Zea mays)-wheat (Triticum aestivium) cropping systems. Indian J. agric. Sci., $78: 881$ 83.

Jensen, M.E. (1983). Design and operation of farm irrigation systems. Am. Soc. Ag. Eng. Mitchigan, USA. pp. 827.

Karam, F.; R. Masaad; T. Sfeir; O. Mounzer and Y. Rouphael (2007). Evapotranspiration and seed yield of field grown soybean under deficit irrigation conditions. Agr. Water Manag. 75: 226-244.

Khalil, F.A.F. and S.G.A. Mohamed (2006). Studies on the inter-relationship among irrigation and maize varieties on yield and water relations using some statistical procedures. Anal. Agric. Sci., Moshtohor. 44(1):393-406.

Klute, A. (1986). Methods of Soil Analysis. $2^{\text {nd }}$ ed. Part 1: Physical and Mineralogical Methods. American Society of Agronomys Madison, Wisconsin, USA.

Mansouri-F.C.; S. A.M.M. Sanavy and S.F. Saberali (2010). Maize yield response to deficit irrigation during low-sensitive growth stages and nitrogen rate under semi-arid climatic conditions. Agric. Water Manage., 97 : 12-22.

Masoero, F.; A. Gallo; G. Giuberti; L. Fiorentini and M. Moschini (2013). Effect of water-saving irrigation regime on whole-plant yield and nutritive value of maize hybrids. J Sci. Food Agric.; 93: 3040-3045.

Matusso, J.M.M. (2016). Growth and yield response of maize (Zea mays L.) to different nitrogen levels in acid soils. Academic Research Journal of Agricultural Science and Research, 4(2): 35-44.

Meysam, A. and A. Sarangi (2013). Deficit irrigation and nitrogen effects on maize growth in semi arid environment. World Applied Sciences Journal, 21 (11): 1687-1692.

Moser, S.B.; B. Feil; S. Jampatong and P. Stamp 2006). Effects of pre-anthesis drought, nitrogen fertilizer rate and variety on grain yield, yield components and harvest index of tropical maize. Agric. Water Manage. $81:$ 41-58. 
Moussa, A.M. and H.H. Abdel-Maksoud (2004). Effect of soil moisture regime on yield and its components and water use efficiency for some wheat cultivars. Annals Agric. Sci., Ain Shams Univ., 49 (2): 982-986.

Obi, C. O.; P. C. Nnabude and E. Onucha (2005). Effects of kitchen waste compost and tillage on soil chemical properties and yield of Okra (Abelmuschus esculentus), Soil Sci., 15:69-76.

Oktem, A.; A. Simsek and A.G. Oktem (2003). Deficit irrigation effects on sweet corn (Zea mays sccharata Sturt) with drip irrigation system in a semi-arid region. Water-yield relationship. Agric. Water Manage., 61: 63-74.

Ouda, S.A.; R. Abou ELenin and M.A. Sheif (2009). Determination of water productivity of maize yield under deficit irrigation in Middle Egypt. The African J.Plant Sci. Biotechnol.,3(1):80-85.

Page, A.L.; R.H. Miller and D.R. Keeny (1982). Methods of Soil Analysis. Part II. Chemical and Microbiological Properties $2^{\text {nd }}$ ed. Amer. Soc. Agron. Inc. Soil Sci. Sco. Amer. Inc. Madison, Wisconsin, USA.

Pandey, R.K.; J.W. Maranville and A. Admou (2000). Deficit irrigation and nitrogen effects on maize in Sahelian environment. II. Shoot growth. Agricultural Water Management, 46(1):1-13.

Payero, J.O.; S.R. Melvin; S. Irmak and D. Tarkalson (2006). Yield response of corn to deficit irrigation in an semiarid climate. Agricultural Water Management. 84: 101-112.

Pereira, L.S. (2006). Irrigated Agriculture: Facing Environmental and Water Scarcity Challenges. International Symposium on Water and Land management for sustainable Irrigated Agriculture, Cukurova University April 4-8, Turkey.

Rayan, A.A.; S.M. El-Marsafawy and K.A. Mohamed (1999). Response of wheat varieties to different sowing dates and irrigation regimes in Upper Egypt. 3rd Conf. on Farm Irrigation and Agroclimatology, Giza Paper No. 44.

Saced, I.M.; R. Abbasi; and M. Kazim (2004). Response of maize (Zea mays) to nitrogen and phosphorus fertilization under agro-climatic condition of Rawalokl. Azad Jammu and Kaslim and Kashmir, Pak. J. Biological Sci., 4:949-952.

Sadik, M.K.; S.A. Ismail; O.H.M. El-Hussieny and R.F. Hashem (2009). Influence of levels and methods of some organic and inorganic fertilizatiers application on maize: 1- Growth and nutrients uptake. J. Agric. Sci., Mansoura Univ., 34(7): 9001-9014.

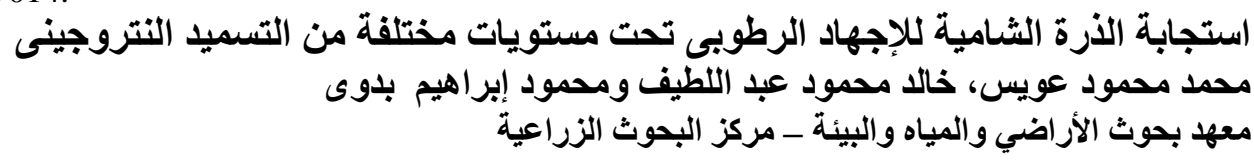

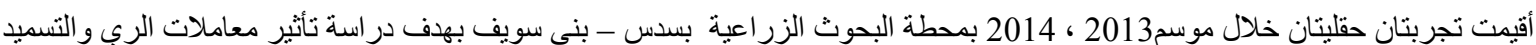

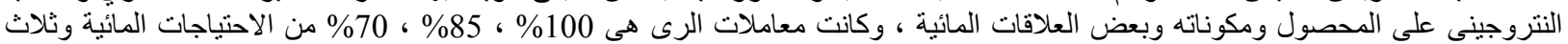

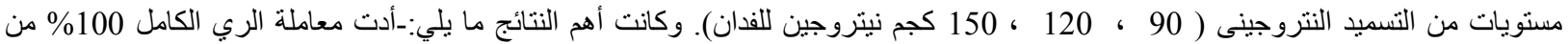

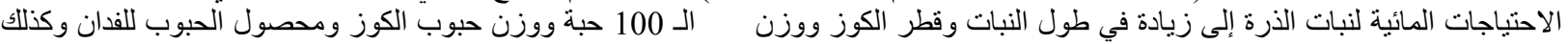

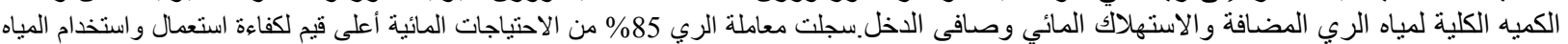

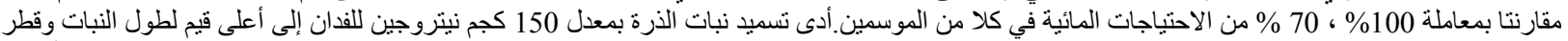

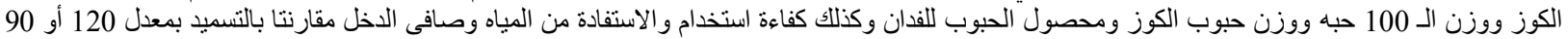

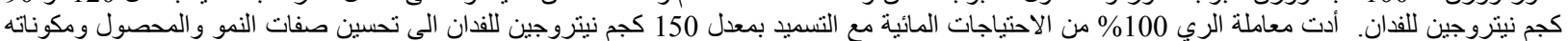

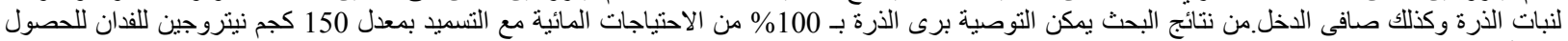
على أعلى إنتاجية وصافى الذخل. 